\title{
Influence of Emotional Intelligence Against Assessment of Final Project (Thesis) Student Semester VIII Economic Education Study Program STKIP Panca Sakti
}

\author{
${ }^{1 \text { st }}$ Rita Aryani \\ Departement of Economic \\ Education \\ STKIP Panca Sakti \\ West Java, Indonesia \\ rita.ar@yahoo.com
}

\author{
$2^{\text {nd }}$ Supriyadi \\ Departement of Economic \\ Education \\ STKIP Panca Sakti \\ West Java, Indonesia \\ supriyadi@panca-sakti.ac.id
}

\author{
${ }^{3 r d}$ Ayu Nurul Amalia \\ Departement of Economic \\ Education \\ STKIP Panca Sakti \\ West Java, Indonesia \\ ayunurulamalia.ana@gmail.com
}

\begin{abstract}
Internal and external factors of students allegedly may affect the assessment of the final project (thesis) students. Detecting from the beginning on the influence of internal and external students is very important as a consideration to optimize the assessment of the final project (thesis) students. This study aims to reveal the influence of emotional intelligence on the assessment of the final project (thesis) students. This research uses survey methodology with simple regression analysis technique, population in this study all students of semester VIII Economic Education Study Program STKIP Panca Sakti, Bekasi City. Samples totaling 65 students were taken using random sampling technique. The data of final assignment (thesis) and emotional intelligence are obtained by using valid and reliable instrument. Data were analyzed by using simple regression analysis.

From the results of data analysis can be concluded that there is influence of emotional intelligence on the assessment of the final project (thesis) students. Coefficient of determination $87.40 \%$, which means that $87.40 \%$ variation of final assignment assessment variable (thesis) can be influenced by emotional intelligence variable.
\end{abstract}

Keywords-Emotional Intelligence, Final Assessment (Thesis)

\section{INTRODUCTION}

Man needs education in his life. Education is an effort so that human beings can develop their own potential through learning process and or other way known and recognized by society. For that, all components of the nation must educate the life of the nation which is one of the goals of the State of Indonesia.

In education we recognize two kinds of factors that affect students and great role to student achievement in learning that is:
1. External factors, ie factors that come from outside students, such as family environment, school and social

2. Internal factors, ie factors that come from within students, such as motivation, creativity, attitude, IQ, EQ, and AQ. These factors support each other and play a major role in the behavior and intellectual ability of students in learning.

Nevertheless we are more inclined to assume that factor IQ is the dominant factor affect student's learning achievement internally. We tend to argue that students who have high IQ perform better than students who have low IQ, or vice versa. In some cases of schooling it turns out that this assumption is not always true, because it can happen that a student with a high IQ earns a low learning achievement. Of course this case raises the question: "Why do students with high IQs get low learning achievement?" In this case many experts stated that the internal factors that affect the success of individual students in learning not only influenced by IQ but also influenced by emotional intelligence (Emotional Intelligence).

Thesis is a written report of the results of research conducted by students with the guidance of Supervisors Supervisors to be maintained before the Examiner Thesis as a requirement to obtain Bachelor degree Thesis is a scientific paper based on the results of research conducted by a student as a final project to obtain a bachelor degree. Based on the definition of layman formulated thesis contains the following components of understanding: Writing, Scientific, Research Results, conducted by students, qualified undergraduate (Rahyono Fx, 2010: 23).

From the observations made by researchers in the course of economic education, School of Teacher Training and Education (STKIP) Panca Sakti, which is located in Jalan Raya Hankam No.54 Jatirahayu, 
Pondok Gede, Kota Bekasi, for the value or score of final assignment (thesis) semester academic year 2016-2017, found the average value for the achievement of this final task (thesis) as much as 33\% get the value of $\mathrm{C}$, the value of $\mathrm{C}$ is the lower limit value of final task graduation, this is a problem that must be looked for way out .

\section{RESEARCH METHOD}

This research uses survey research method with data analysis using simple regression analysis. The population of this research is the students of semester VIII who are completing the final project (Thesis). The sampling technique used is random sampling. Data collection using the final assignment assessment instrument (thesis) with a score range of 0-100 and the emotional intelligence instrument in the form of attitude scale with score range 38-190. The final task assessment instrument (thesis) is valid and has reliability of Alpha 0,827 . The instrument of emotional intelligence is also valid and reliable with reliability Alpha dimension I 0.769 and dimension II of 0.618. Data analysis technique using simple linear regression analysis where emotional intelligence as independent variable $(\mathrm{X})$ and result of final assignment (thesis) (Y) as dependent variable.

\section{RESULT AND DISCUSSION}

Description of emotional intelligence score data is presented in the following table.

Table 1. Description of emotional intelligence score \& final assessment results

\begin{tabular}{|l|l|c|c|}
\hline \multicolumn{2}{|c|}{} & $\begin{array}{c}\text { Kecerdasan } \\
\text { Emosional }\end{array}$ & $\begin{array}{c}\text { Penilaian Tugas } \\
\text { Akhir (Skripsi) }\end{array}$ \\
\hline \multirow{2}{*}{ N } & Valid & 65 & 65 \\
\cline { 2 - 4 } & Missing & 0 & 0 \\
\hline Mean & 107.9385 & 88.9538 \\
\hline Std. Deviation & 14.65848 & 5.89605 \\
\hline Minimum & 86 & 76 \\
\hline Maximum & 132 & 96 \\
\hline
\end{tabular}

The results of regression analysis in two student scoring groups using SPSS software can be summarized as follows.

Table 2. Results of Linear Regression Analysis

\begin{tabular}{|c|c|c|c|c|c|c|}
\hline \multicolumn{7}{|c|}{ Coefficients $^{n}$} \\
\hline \multirow{2}{*}{\multicolumn{2}{|c|}{ Model }} & \multicolumn{2}{|c|}{ Unstandardized Coefficients } & \multirow{2}{*}{$\begin{array}{c}\text { Standardized Coefficients } \\
\text { Beta } \\
\end{array}$} & \multirow{2}{*}{$\mathrm{t}$} & \multirow{2}{*}{ Sig. } \\
\hline & & B & Std. Error & & & \\
\hline \multirow{2}{*}{1} & (Constant) & 48.36 & 1.957 & & 24.706 & 0 \\
\hline & Kecerdasan Emosional & 0.376 & 0.018 & 0.935 & 20.926 & 0 \\
\hline
\end{tabular}

From the above table obtained the regression equation: $\mathrm{Y}=48.360+0.376 \mathrm{X}$. From result of analysis obtained thit $=20,926$ and $\mathrm{p}$-value $=0.000$ / $2=0<0,05$ or Ho rejected. Thus, "Emotional intelligence positively affects the assessment of final project (thesis) students."
Table 3. Anova Table

\begin{tabular}{|c|c|c|c|c|c|c|c|}
\hline \multicolumn{8}{|c|}{ ANOVA Table } \\
\hline & & & $\begin{array}{l}\text { Sum of } \\
\text { Squares }\end{array}$ & df & $\begin{array}{l}\text { Mean } \\
\text { Square }\end{array}$ & $\mathrm{F}$ & Sig. \\
\hline \multirow{5}{*}{$\begin{array}{l}\text { Penilaian } \\
\text { Tugas Akhir } \\
\text { (Skripsi) } \\
\text { Kecerdasan } \\
\text { Emosional }\end{array}$} & \multirow{3}{*}{$\begin{array}{l}\text { Between } \\
\text { Groups }\end{array}$} & (Combined) & 2125.237 & 8 & 265.655 & 149.327 & .000 \\
\hline & & Linearity & 1945.037 & 1 & 1945.037 & 1093.323 & .000 \\
\hline & & \begin{tabular}{|} 
Deviation \\
from Linearity
\end{tabular} & 180.199 & 7 & 25.743 & 14.470 & .000 \\
\hline & \multicolumn{2}{|c|}{ Within Groups } & 99.625 & 56 & 1.779 & & \\
\hline & \multicolumn{2}{|l|}{ Total } & 2224.862 & 64 & & & \\
\hline
\end{tabular}

Linearity test of regression line equation is obtained fcount $(\mathrm{Tc})=14,470$, with $\mathrm{p}$-value $=0,000$ $<0,05$. This means that $\mathrm{H} 0$ is received or the regression equation $\mathrm{Y}$ over $\mathrm{X}$ is linear or a linear line.

Table 4.

Anova

ANOVA $^{a}$

\begin{tabular}{|c|l|c|c|c|c|c|}
\hline \multicolumn{2}{|c|}{ Model } & Sum of Squares & df & Mean Square & F & Sig. \\
\hline \multirow{3}{*}{1} & Regression & 1945.037 & 1 & 1945.037 & 437.91 & $.000^{\circ}$ \\
\cline { 2 - 8 } & Residual & 279.824 & 63 & 4.442 & & \\
\cline { 2 - 8 } & Total & 2224.862 & 64 & & & \\
\hline
\end{tabular}

. Dependent Variable: Penilaian Tugas Akhir (Skripsi)

b. Predictors: (Constant), Kecerdasan Emosional

The significance test of regression line equation is obtained Fcount (b / a) $=437,908$, and p-value = $0,000<0,05$ or $\mathrm{H} 0$ is rejected. Thus, the regression of $\mathrm{Y}$ over $\mathrm{X}$ is significant or the emotional intelligence affects the students' final assignment (thesis).

Table 5. Model Summary

\begin{tabular}{|c|c|c|c|c|c|c|c|c|c|}
\hline \multirow[b]{3}{*}{ Model } & \multicolumn{8}{|c|}{ Model Summary } & \\
\hline & \multirow[b]{2}{*}{$\mathrm{R}$} & \multirow[b]{2}{*}{ R Square } & \multirow[b]{2}{*}{$\begin{array}{c}\text { Adjusted R } \\
\text { Square }\end{array}$} & \multirow{2}{*}{$\begin{array}{l}\text { Std. Error } \\
\text { of the } \\
\text { Estimate }\end{array}$} & \multicolumn{5}{|c|}{ Change Statistics } \\
\hline & & & & & $\begin{array}{l}\text { R Square } \\
\text { Change }\end{array}$ & F Change & df1 & $d+2$ & $\begin{array}{l}\text { Sig. } F \\
\text { Change }\end{array}$ \\
\hline 1 & $.935^{3}$ & 874 & .872 & 2.10752 & .874 & 437.908 & 1 & 63 & .000 \\
\hline
\end{tabular}

The significance test of correlation coefficient is obtained $(\mathrm{rxy})=0,935$ and fcount $=437,908$, with $\mathrm{p}$ value $=0,000<0,05$. This means $\mathrm{H} 0$ is rejected. Thus, the correlation coefficient of $\mathrm{X}$ and $\mathrm{Y}$ is significant or significant. While the coefficient of determination is $\mathrm{R}$ Square $=0.874$, which means that $87.40 \%$ variation of final assignment assessment variable (thesis) can be influenced by emotional intelligence variable.

The result of the research reveal the emotional intelligence influence to the final assignment (thesis) student, thus the result of this research support the result of research conducted by Supriyadi (2011), express: Emotional intelligence influence to result of study of sharia insurance; This is consistent with Goleman and Epstein's opinion in Achir who say that students who have high emotional intelligence have the ability to control and manage their emotions better in the learning process, they have a high awareness, self-control, self-motivation, empathy or attention to the lessons, and being able to put themselves in the classroom as good students. In learning, students who have high emotional intelligence tend to be active and have a high curiosity about the lessons given by the teacher. 


\section{CONCLUSION}

This study concludes that: (1) Emotional intelligence significantly affects the assessment of the final project (thesis) students. (2) $87.40 \%$ variation of final assessment variable (thesis) is influenced by emotional intelligence variable.

\section{REFERENCES}

[1] End, Yaumil Agoes. (1998). "Towards Personal Success with IQ, Social Skills, and Emotional Maturity," One-Day Seminar Papers. Jakarta: University of Indonesia.

[2] Alder, Harry. (2001). Boost Your Intelligence, translation Kristina Prianingsih. Jakarta: Erland.

[3] Arikunto, S. (2009). Management Research. Jakarta: PT Rieka Cipta.

[4] Atwater. (1993). Expressions of Emotion, The Encyclopedia. New York: Harvard University.

[5] Bloom, Benjamin S. et al. (1981). Taxonomy of Educational Objective: Handbook I. New York: Longman Inc.

[6] Briggs, Leslie J. (1979). Instructional Design Principles and Aplication. New Jersey: Newelence and Printice Hall.

[7] Catalina, C. (1992). Learning, third ed. New Jersey: Prentice Hall International

[8] Goleman, Daniel. (1995). Emotional Intelligence. New York: Scientific
[9] American.

[10] Hamalik, Oemar. (1991). A New Approach to Teaching and Learning Strategies

[11] Based on CBSA. Bandung: CV. New Light.

[12] Iskandar, Mukhtar. (2010). Learning design based on Information and Communication Technology. Jakarta: Gaung Persada Press.

[13] Johana E. Prawitasari. (1995). Know Emotions Through Nonverbal Communication. Yogyakarta: Faculty of Psychology UGM.

[14] Kadir. (2010). Statistics for Social Sciences Research. Jakarta: PT Rosemata

[15] Sampurna.

[16] Kartono, K. (1996). Introduction to Social Research Methodology. Bandung: CV

[17] Mandar Maju.

[18] Miarso, Yusufhadi. (1989). Monograph of Educational Technology. Jakarta: Directorate General of Higher Education, Department of Education and Culture

[19] National Education Number 20. (2003). Materials Socialization, Depdiknas.

[20] Supriyadi. (2011). "The Influence of Learning Method and Emotional Intelligence on Sharia Student Learning Outcomes of SMK Al Wahyu". Thesis. Graduate Program, Prof. University Dr. Hamka. 